\title{
EUROPEAN MARITIME SAFETY AGENCY
}

\author{
POPA GEORGE-DOREL \\ “Ovidius” University of Constanta, Romania
}

\begin{abstract}
This European Agency has been established in 2002 through Regulation (EC) no 1406/2002 of the European Parliament and of the European Council. The main mission of European Maritime Safety Agency is to prevent and combat the risk of maritime accidents, maritime pollution from ships and to prevent the loss of human life during the navigation. This agency represents the technical institution providing the European Union with the necessary means to enhance maritime safety and to prevent and combat ship pollution. European Maritime Safety Agency should assist the European Commission in developing European Union legislation in the area of navigation safety and prevention of pollution by vessels. E.M.S.A. should provide the necessary support to ensure the implementation of European legislation in this area by assisting the European Commission. European Maritime Safety Agency is performing the tasks assigned by the European Union legislation on navigation safety and prevention of the vessels pollution.
\end{abstract}

Keywords: Vessels, Maritime safety, European Union, Maritime pollution.

\section{INTRODUCTION}

"Maritime security"[1] is the combined preventive measures taken in order to protect shipping and port facilities against threats of intentional unlawful acts. The security objective should be achieved by adopting appropriate measures in the field of maritime transport policy, without prejudice to the rules of the Member States in the field of national security, defence and public security, and in combating financial crimes against the States. Taking in account the main goal of the Agency, it is necessary to explain in detail the term of vessels pollution, used in the context of maritime law accepted on international level. European Maritime Safety Agency has been founded in 2002. The establishment of the Agency was possible after adoption of European Union of many acts and legislation related to maritime security. These measures have been taken because of major shipping disasters in the area of European waters, such as those involving the ferry Estonia and the oil tankers Erika and Prestige. It was felt that a specialised European Agency should be created to permanently overview the implementation of this legislation and help in maritime supervision of the European seas. Marine pollution is caused mainly by oil and gas installations and should be understood as pollution by oil or any substance other than oil considered dangerous. This kind of substance, introduced into the sea water, might create serious hazards for human health or affect living resources and marine life. According to the European Law, the Agency is obliged to provide operational assistance to the Member States and European Commission. This assistance includes services such as the Union Maritime Information and Exchange System, the European Satellite Oil Monitoring Service, the European Union Long Range Identification and Tracking Data Centre and the EU Port State Control inspection data base (Thetis). Another aim of Agency is to fight using its own ways the growing risk of piracy. In this respect, the Agency is obliged to forward immediately to competent national authorities and other relevant bodies, detailed information about the position of vessels under the flag of Member States transiting through dangerous areas. In this regard, the Agency could provide, upon request, relevant vessel positioning and other geographical data to competent national authorities and European Union institutions (e.g. FRONTEX and Europol). This information and data might facilitate preventive measures against worldwide piracy and other sea dangerous situations having in mind the salvation of the crew and of the load transported at that moment.

\section{EUROPEAN MARITIME SAFETY AGENCY STRUCTURE}

In order to accomplish its tasks established by Regulation (EC) no 1406/2002 of the European Parliament and of the European Council, the Agency is led by an Executive Director reporting to the Administrative Board. The Executive Director is responsible for the setting up, running and development of the Agency. The good functioning of the Agency requires that its

Executive Director is appointed on the grounds of merit and documented administrative and previous managerial skills. The competence and experience relevant for maritime safety and prevention of pollution by ships are other key elements in the appointment decision. The executive Director should perform his duties with complete independence and flexibility as to the organisation of the internal functioning of the Agency. The Executive Director should prepare and take all necessary steps to ensure the proper accomplishment of the working programme of the Agency. The Executive Director should yearly prepare a draft general report to be submitted to the Administrative Board, should thinking out the estimates of the revenues and expenditure of the Agency and should implement the budget immediately after its approval. The Administrative Board consist of one representative of each Member State and four representatives of the 
European Commission. Each member has a high level of expertise in this area. In order to ensure the appropriate level of expertise and experience in the Administrative Board, the European Commission should nominate independent professionals from these sectors as board members without the right to vote. These specialists on the basis of their personal merit and experience in the field of maritime safety and prevention of pollution by ships are very useful tools for Agency. It is important to be mentioned that they are not representatives of any particular professional organisations or other institutions.

The Agency [2] is made up of following units:

Department A: Corporate Services[3] having as main goal to provide high quality and timely support to European Maritime Safety Agency's core operational business, and to assist management and staff in the areas of human resources, legal and financial affairs, information technology, facilities and logistics, meeting and conference management, protocol, and budget planning and monitoring.

Department B: Implementation Service [4] having as main mission verification and monitoring of the implementation of maritime safety legislation falling under the umbrella of Agency. This department is responsible for the activities in the fields of classification societies, the training of seafarers, navigation security and monitoring their implementation of European Union maritime legislation. This department assists the Commission in its monitoring of Member States' implementation of the maritime security requirements, by providing technical assistance in its inspections of vessels, companies and security organizations.

Department C: Operations Service [5] having as main goal providing of operational assistance to Member States and the European Commission in the field of preventing and combating sea pollution. Department C facilitates technical cooperation in the area of European Union vessel traffic and satellite monitoring.

\section{GENERAL INFORMATION ABOUT EUROPEAN MARITIME SAFETY AGENCY}

According to Regulation (EC) no 1406/2002 of the European Parliament and of the European Council, the Agency is obligated to work with the European Commission and with the Member States.

Cooperation with the European Commission should take place in various areas. First of all, the Agency should be part in the necessary activities for updating and developing relevant legal acts of the European Union. In this domain Agency will permanently follow up the development of international legislation.

The Agency will supervise the effective implementation of relevant legal provision by carryingout visits and inspections in the ports and at relevant ships. As well the Agency should provide technical assistance to the Commission in the performance of the inspection tasks in maritime areas and should carry out the identification of possible follow-up measures resulting from specific research projects in its area of responsibility. As have been mentioned the cooperation with the Member States of European Union have an important place within Agency's tasks. From this point of view, the Agency is called to develop technical solutions and provide technical assistance, to the building up of the necessary national capacity for the implementation of relevant legal provisions of the European Union in maritime domain. To achieve this goal EMSA periodically organize, relevant training activities in areas situated on the responsibility of the Member States.

Taking in account the latest evolutions, the Agency periodically issue common rules and standards for ship inspection and survey organizations, as well, for the relevant activities of maritime administrations. When a Member State request, the Agency support with additional means pollution response actions in case of pollution caused by ships or marine pollution caused by oil and gas installations. In the area of maritime traffic monitoring, the Agency shall in particular promote cooperation between riparian States in the shipping areas concerned, as well as develop and operate the European Union Long-Range Identification and Tracking of Ships European Data Centre and the Union Maritime Information and Exchange System. In the area of the investigation of marine casualties and accidents the Agency will provide operational support to these Member States concerning investigations related to serious casualties and it will carry out safety investigation reports. It is very important to identify and to permanently add value at European Union level in terms of avoiding causalities and maritime incidents.

Each year the Agency should present a yearly report concerning the marine casualties and incidents in the European seas. Another important task of the agency is to provide, upon request, the relevant information about vessel positioning to the competent national authorities and relevant Union bodies. This information will be used to facilitate measures against threats of piracy and of intentional unlawful acts. Another important task of the Agency is to collect record and evaluate the technical data in the maritime area and to develop the additional databases in this respect. Providing objective, reliable information and data, will allow the European Commission and the Member States of European Union to take the necessary steps to improve their actions and measures [6].

As well, the Agency will have permanently in its attention improving the identification and pursuit of ships causing troubles or being pollution source. In this respect, EMSA is allowed to propose penalties for incidents and infringements. Using the European Satellite Oil Monitoring Service, the marine oil pollution caused by oil and gas installations will be monitored by the Agency. In such cases, EMSA will analyze the extent and environmental impact of the pollution the environmental perspective. The Agency examines IMO requirements and gathers basic information on potential threats to maritime transport and the marine environment. When is requested, European Maritime Safety Agency carry out examination of the feasibility and the implementation of projects supporting the establishment of the European maritime transport space without any barriers.

Last but not least, the Agency is facilitating exchange of best practices in maritime training and 
education in the European Union territory. This goal is accomplished by providing information on European Union exchange programs relevant for maritime training and education [7]. The Agency should, sometime carry out visits to Member States in accordance with the methodology established by the Administrative Board. The Agency will inform the Member State the aim of the mission, the names of the officials and the date on which the visit starts and its expected duration. These inspections carried out by the Agency will aim the implementation of the common rules and standards for ship inspection and survey organizations.

As well, the verifications are targeting the training and certification of seafarers in third countries. At the end of each inspection the Agency will edit a report. The report will contain the main aspects of the verifications, the conclusions and shortcomings discovered during the visit. The report will be send to the European Commission and to the Member State. The Commission based on the report analyses and recommendations of EMSA will engage further discussions with Member States in order to facilitate the dissemination of good working practices and to correct the eventually gaps and errors [8].

\section{FINANCIAL ASPECTS CONCERNING EUROPEAN MARITIME SAFETY AGENCY}

The main part of the budget of European Maritime Safety Agency is coming yearly from the European Union budget. Nevertheless, according to the European law is allowed the participation of third countries in the activity of Agency. The mentioned third country should conclude agreements with the European Union. According to the adopted agreements the third country is applying the Community law in the field of maritime safety, maritime security, prevention of pollution and response to pollution caused by ships [9].

In these cases is possible a financial contributions from any third country which participates in the work of the Agency. And the third financial source of the European Maritime Safety Agency is the fees and charges for publications, training and any other services and technical advices provided by the Agency. Yearly, the Agency's budget is adopted in such way that expenditures should cover all the expenses for staff and administrative, infrastructure and operational costs. The Executive Director of the European Maritime Safety Agency should elaborate a draft of estimates of the Agency's revenue and expenditure for the following year, on the basis of activities carried out in the present year and a draft establishment plan. Yearly, the Administrative Board, on the basis of a draft statement of estimates of European revenues and detailed expenditures, produces a statement of estimates of revenue and expenditure for the European Maritime Safety Agency for the following financial year [10].

The statement of estimates costs and revenues should be forwarded by the European Commission to the European Parliament and the European Council (is the budgetary authority, according to the European legal provisions) together with the draft general budget of the European Union. On this basis, of the statement of estimates, the European Commission should enter in the draft general budget of the European Union the estimates it deems necessary for the establishment plan and the amount of the subsidy to be charged to the general budget, together with a description of and justification for any other difference.

The budget of the European Maritime Safety Agency will be adopted by the Administrative Board of the Agency. The draft of the budget will be final following final adoption of the general budget of the European Union. If it is necessary, the budget will be adjusted accordingly, in the same time with the annual working program of the Agency. After the adaptation of the budget, the Executive Director is responsible for its permanent implementation according to the approved plan. The control of the budget lied in the hands of the Executive Director, European Commission and Court of Auditors. Yearly, the Agency's accounting officer should communicate the provisional accounts to the European Commission's accounting bureau together with a detailed report on the budgetary and financial management of the year. The financial report concerning the budgetary and financial management will be also forwarded to the European Parliament and the European Council.

The Court of Auditors and OLAF may carry out, if necessary, various verifications concerning the Agency's funding and the agents responsible for allocating it. The European Anti-fraud Office (known as OLAF, due to the French language: Office Européen de Lutte Antifraude) is charged by the European law with the protection of the financial interests of the European Union. Among its important tasks are: the fight against fraud affecting the European Union money, the prevention and fight against corruption and any other irregular activity, including misconduct, within the institutions of the European Union. OLAF is permanently supervising the European Union money to be used in a transparent and costeffective manner.

\section{CONCLUSIONS}

In the future, the European Maritime Safety Agency will pay a special attention on its priority tasks in the area of maritime safety. Nevertheless, the Agency should receive a number of new priority and tasks reflecting the development of maritime safety policy and the general marketing strategies at European Union and worldwide level [11]. In the present context, of the worldwide financial and economic crisis and taking in account the budget constraints of the European Union, serious screening and redeployment activities are necessary to ensure cost and budget efficiency. Moreover, the restructuring of the Agency is necessary to avoid any overlapping between its tasks and other agencies tasks. Staffing needs for the new core and ancillary tasks should, as a matter of principle, be covered through internal redeployment by the Agency.

At the same time, the Agency should receive, where appropriate, funding from other parts of the Union budget, in particular from the European Neighborhood Policy instrument. The carry out any new tasks by the Agency should be undertaken measures taking in account the budgetary limits. The operational activities 
should be carrying out within the limits of the current financial possibilities and the Agency's budget. Therewith, the operational tasks should take into consideration the necessity of avoiding prejudice to the negotiations and decisions concerning the future multiannual financial plan. Recent worldwide events emphasized the risks of offshore oil and gas exploration. The activities in the area of the maritime transport and the marine harvesting took new form lately.

The Agency's response capabilities for pollution should increase in the nearest future. As well, its expertise in the field of pollution by hazardous and noxious substances should be increased. In this context, this expertise will be used to cover pollution cases originating from such activities, at the request of any affected member state of the European Union. Periodical evaluation should take place to evaluate the impact of Agency activity as well as the utility, relevance, added value and effectiveness of the its working procedures. The evaluation shall take into account the opinions of stakeholders, at both European and national level [12]. From this point of view the assessments might end the possible need to modify the Agency's tasks and function ways.

These types of evaluations and recommendations regarding European Maritime Safety Agency should be periodically analyzed by the each Member State. Based on this analyzes, may be elaborated changes to the rules and regulation and implemented good practices within the activity of the Agency. The evaluations and recommendations should be made public, to ensure the transparent process in the activity of European Maritime Safety Agency. Additionally to the obligation of the European Commission to submit an annual report to the European Parliament and the European Council regarding the activity of the Agency may be take in consideration the annual opinion of the Member State in this regard. Each Member State should have the opportunity to present in public its opinion about the activity of the Agency identifying further efficiency gains and to issue proposals for modifying its objectives and tasks.

\section{REFERENCES}

[1] Regulation (EC) No 725/2004 of the European Parliament.

[2] Regulation (EC) no 1406/2002 of the European Parliament and of the European Council.

[3] www.emsa.europa.eu

[4] www.emsa.europa.eu

[5] Regulation no 100/2013 of the European Parliament and of the Council of 15 January 2013 amending Regulation (EC) no 1406/2002 establishing a European Maritime Safety Agency

[6] Regulation (EC) no 1406/2002 of the European Parliament and of the European Council.

[7] Regulation (EC) no 1406/2002 of the European Parliament and of the European Council.

[8] Regulation (EC) no 1406/2002 of the European Parliament and of the European Council.

[9] Regulation (EC) no 1406/2002 of the European Parliament and of the European Council.

[10] Regulation (EC) no 1406/2002 of the European Parliament and of the European Council.

[11] GRIGORUT, C., Marketing, BREN Publishing House, Bucharest, 2004.

[12] BRASOVEANU, F. International law among sciences, diplomacy and politics, In Honorem Dumitru Mazilu, Universul Juridic Publishing House, 2011. 